2019 ECONOMY Vol. 14. No. 1

doi 10.17072/1994-9960-2019-1-145-159

UDC 338.26(454.4)

LBK 65. 290-2 (4 Pym)

JEL Code C610, C630

\title{
ORGANIZATIONAL STRUCTURE AS A FACTOR OF DEVELOPMENT OF CORPORATE SOCIAL RESPONSIBILITY IN ROMANIAN COMPANIES
}

\author{
Catalina Silvia Crisan-Mitra \\ ORCID ID: 0000-0002-4048-3380, e-mail: catalina.crisan@econ.ubbcluj.ro
}

Babeş-Bolyai University (58-60, Teodor Mihali st., Cluj-Napoca, 400591, Romania)

The role of corporate social responsibility for the development of fundamental basis of social-economic interaction on sustainable development basis is significant for the existing corporate relations in the global economy. Corporate social responsibility means a voluntary initiative of separate corporations to implement a system social policy in the interests of society in general through the implementation of socially significant obligations established by laws, ethical standards, adopted rules of behaviour. In this regard the importance to study the corporate social responsibility phenomenon is that corporations with their socially significant behaviour predetermine social values in society in general and determine the vector of its socio-economic development. Considering the fact that the system of corporate social responsibility is based on labour relations incorporated into social-economic mechanism of a corporation and the mechanism in its turn is based on a company's organizational structure the impact of an organizational structure on the corporate social responsibility practice is investigated in the research. The purpose of the article is to assess the impact of organizational structures of a company on the development of the systems of corporate social responsibility and to reveal differences in the corporate social responsibility systems of companies with different types of organizational structures. To achieve the aim of the study a theoretical review of approaches to understanding the essence of organizational structures and models of corporate social responsibility has been made. To analyse organizational structures we have used a synthetic approach that differentiates the structures into two types: mechanistic (with a high level of hierarchy and division of labour) and organic (flexible and better adapted to the rapid change of external conditions, including the emergence of new technologies). The hypothesis of the research is the assumption that companies with organic organizational structures are more progressive in the development of corporate social responsibility systems and the introduction of the principles of corporate social responsibility into their business practices. The study is based on social and ecological reports of Romanian companies that have more than 249 employees. The case-study method, interviewing, the tools of economic-mathematical analysis of data have been used in the research. While analyzing the contemporary status of the corporate social responsibility in Romania and 87 results of the questioning of the representatives of the Romanian companies we have come to the conclusion that despite the type of the organizational structure the key factors of the development of the system of corporate social structure are a company image and its reputation at the market, practice of purchasing (e.g. the compliance of the ethical code of a company by business partners and suppliers), the assessment of human rights in the company by business partners and industry trends of sustainable development. At that, the hypothesis that companies with mechanistic and organic organizational structures differently assess the role of the factors of corporate social responsibility. Thus, for companies with mechanistic organizational structures, image and reputation at the market, assessment of human rights by business partners, procurement practices, motivation and competence of personnel, and the absence of discrimination in remuneration of men and women are of fundamental importance in the development of corporate social responsibility systems. Companies with the organic type of organizational structure significantly appreciate the image and reputation at the market, as well as the level of internationalization of a company, the use of ECO labels, industry trends of sustainable development and production efficiency. As regards the advantages of the introduction of corporate social responsibility principles in the activities of companies, we have discovered that the differences are mainly observed in the average estimates of the analyzed factors in favour of companies with organic organizational structures. Results obtained in the investigation allow us to construct a profile of corporate social responsibility of companies with different types of organizational structures, to identify the advantages of the development of the system of corporate social responsibility and to make strategic priorities of socially oriented activity of a company more detailed. And further studies will be devoted to this aspect.

Keywords: corporate social responsibility, organizational structure, organic organizational structure, mechanistic organizational structure, factors of development of corporate social responsibility, sustainable development, efficiency.

(C) Crisan-Mitra C.S., 2019 


\title{
ОРГАНИЗАЦИОННАЯ СТРУКТУРА КАК ФАКТОР ФОРМИРОВАНИЯ МОДЕЛИ КОРПОРАТИВНОЙ СОЦИАЛЬНОЙ ОТВЕТСТВЕННОСТИ В РУМЫНСКИХ КОМПАНИЯХ
}

\author{
Каталина Сильвия Крисан-Митра \\ ORCID ID: 0000-0002-4048-3380, e-mail: catalina.crisan@econ.ubbcluj.ro
}

Университет Бабеш-Бойяи (Румыния, 400591, г. Клуж-Напока, ул. Теодора Михали, 58-60)

В сложившихся на современном этапе корпоративных отношениях в глобальной экономике сложно переоценить роль корпоративной социальной ответственности в создании фундаментальных основ социально-экономического взаимодействия на принципах устойчивого развития. Корпоративная социальная ответственность представляет собой добровольную инициативу отдельных корпораций по реализации системной социальной политики в интересах общества в целом через выполнение социально значимых обязательств, установленных законами, нормами этики, принятыми правилами поведения. В связи с этим актуальность исследования феномена корпоративной социальной ответственности заключается в том, что корпорации своим социально значимым поведением предопределяют социальные ценности в обществе и определяют вектор его социально-экономического развития. Принимая во внимание тот факт, что базисом системы корпоративной социальной ответственности выступают трудовые отношения, встроенные в социально-экономический механизм корпорации, основу которого составляет организационная структура компании, мы исследуем влияние организационной структуры на практику корпоративной социальной ответственности с целью выявления различий в системах корпоративной социальной ответственности компаний с разными типами организационных структур. Сделан теоретический обзор подходов к пониманию сущности организационных структур и моделей корпоративной социальной ответственности. В анализе организационных структур использован синтетический подход, основанный на их разделении на два типа - механистические (с высоким уровнем иерархии и степени разделения труда) и органические (гибкие и лучше приспособленные к быстрой смене внешних условий, включая появление новых технологий) организационные структуры. Гипотезой исследования является предположение о том, что компании с органическими организационными структурами являются более прогрессивными в развитии систем корпоративной социальной ответственности и внедрении принципов корпоративной социальной ответственности в свою хозяйственную практику. Информационной базой исследования выступила социальная и экологическая отчетность румынских компаний с численностью сотрудников более 249 человек. Методы исследования - case-study, интервьюирование, инструментарий экономикоматематического анализа данных. В ходе анализа современного состояния корпоративной социальной ответственности в Румынии и результатов 87 опросов представителей румынских компаний установлено, что вне зависимости от типа организационной структуры важнейшими факторами развития системы корпоративной социальной ответственности являются имидж компании и ее репутация на рынке, практика закупок (например, соблюдение деловыми партнерами и поставщиками этического кодекса компании), оценка бизнес-партнерами соблюдения прав человека в компании, отраслевые тенденции устойчивого развития. При этом подтверждается гипотеза о том, что компании с механистическими и органическими организационными структурами по-разному оценивают роль факторов корпоративной социальной ответственности. Так, для компаний с механистическими организационными структурами принципиальное значение в развитии систем корпоративной социальной ответственности имеют имидж и репутация на рынке, оценка бизнес-партнерами соблюдения прав человека, практика закупок, мотивация и компетенции персонала, отсутствие дискриминации в оплате труда мужчин и женщин. В компаниях с органическим типом организационной структуры имидж и репутация на рынке имеет больший вес, так же как и уровень интернационализации компании, использование этикеток ЕСО, отраслевые тенденции устойчивого развития и производственная эффективность. Что касается выгод от внедрения принципов корпоративной социальной ответственности в деятельность компаний, установлено, что различия преимущественно наблюдаются в средних оценках анализируемых факторов в пользу компаний с органическими организационными структурами. Полученные результаты дают возможность построить профили корпоративной социальной ответственности компаний с разными типами организационных структур, идентифицировать преимущества развития систем корпоративной социальной ответственности и детализировать стратегические приоритеты социально ориентированной деятельности компаний, что составляет перспективы будущих исследований автора.

Ключевые слова: корпоративная социальная ответственность, организачионная структура, органическая организаџионная структура, механистическая организационная структура, факторы развития корпоративной социальной ответственности, устойчивое развитие, эффективность. 


\section{Introduction}

7 he restructuring of the economic systems of the Eastern European countries in the 1990s and their integration into the world economic space determined the urgent need for the rapid implementation of corporate management principles, which had not existed before. From the point of view of the world trends the economy demonstrates the enormous need for investment, primarily to achieve the goals of sustainable development. One of the factors contributing to this objective is the recognition and improvement of corporate management principles. On the one hand it involves guaranteeing the protection of investors' interests, and on the other hand, ensuring mutually beneficial economic cooperation of all stakeholders - investors, top management, labour collectives, the state - and other stakeholders, as well as effective and stable development of a company in general.

In the implementation of socialeconomic function in the activities of modern companies, particular attention is paid to the introduction of corporate social responsibility (hereinafter CSR) that arouses intense interest in the theory and practice of modern management of the "new" economic systems of Eastern Europe. This is a long process as it requires understanding and absolute recognition of both guarantees of protection of investors' interests and integration of economic interests of individual corporations into the system of the society values. In addition, a deep study of the factors that influence the successful implementation of CSR is required.

CSR is known to include a number of elements that directly or indirectly contribute to the creation of material opportunities to maintain modern quality life standards of the society and the development of human capital as a key condition for intensive economic growth and sustainable development. Accordingly, an approach to the identification of opportunities and promising factors of CSR development through the organizational mechanism of company management is suggested in the article. In other words, considering the fact that the system of CSR is based on labour relationships incorporated into a social-economic mechanism of a corporation that, in its turn is based on an organisational structure of a company, it is necessary to analyze the impact of the formed organizational structure on the CSR practice. Respectively, the purpose of the study is to assess the influence of organizational structures of companies on the development of CSR systems and to identify differences in the systems of CSR of companies with different types of organizational structures. To achieve the purpose of the research we suggest using a synthetic approach in the analysis of organizational structures. The approach differentiates the structures into two types: mechanistic (with a high level of hierarchy and division of labour) and organic (flexible and better adapted to the rapid change of external conditions, including the emergence of new technologies) organizational structures.

Literature review implies that this approach is generally consistent with the modern view of the relationship between the organizational structure of a company and its CSR system.

Thus, nowadays CSR is a strategic management task in the departments and management structures of the companies. Reporting relationships, the grouping of organizational members, and the systems for coordination, communication, and integration across the organization inherently impacts the practices companies' way of implementing a sustainable strategy. Taking into consideration the degree of complexity, formalization, and centralization in CSR will determine the relationship between organizational structure and the management approach towards practices implemented, in terms of complexity and impact [1].

T. Burns and G.M. Stalker [2] identified two types of organizational structures the: organic and mechanistic structures, enabling different approaches and priorities leading to different results and impact. The mechanistic organization is hierarchical and bureaucratic, is characterized by a highly centralized authority, formalized procedures, and practices, and specialized functions. These structures demonstrate great 
complexity, a high degree of formalization, and are highly centralized. It is relatively easier and simpler to organize, and difficult to implement change but it enables competition among the managerial ranks which often leads to conflict [3].

Organic structures are characterized by homogeneity, the horizontal interactions low degree of specialization, decentralized decision-making and direct supervision. The few layers of management make the structures more dynamic providing employees a greater freedom to act. According to D.A. Morand [4], an organic organization is a dynamic network of multi-talented individuals who perform a variety of tasks. In organic systems, centers of control and authority and communication are problem specific [5]. Because there is not a designed top management in an organic structure, the top management is defined by task-relevant specialized knowledge with a great autonomy and control $[6 ; 7]$. The team self-management is used a participatory management where team members have a high level of decisional autonomy and control in daily activities [8].

While organic structures provide more advantageous conditions for creative and innovative responses to emerging challenges [9; 10] mechanistic structures restrict organizational potential to generate innovative solutions [11].

Undeniably, it is necessary to consider the fact that the current trends in the global economy (digitalization, globalization and development of artificial intelligence systems, the transition of public administration to electronic space), forcing corporations to improve organizational efficiency and search of new types of organizational structures, involving the modernization of traditional principles of organization, such as hierarchy and unity of command. The emergence of design, matrix, network or conglomerate types of organizational structures proves this fact.

In project groups, for example, all team members and resources allocated to a specific task are fully subordinate to the project manager. Matrix structures combine operational and project activities to ensure the integration of all activities and resources of project managers, who may be below line managers in the functional structure. Network structures involve the elimination of hierarchy and the construction of self-organizing systems based on the recognition of environmental influences and the preparation of the response of the control object. The response is based on the analysis of huge amount of data. At the same time, conglomerate or integrated approach allows us to combine all possible types of organizational structures within one corporation.

Since the development of these particular types of organizational structures is due to the high level of development of the corporate management system in the country in general, for the purposes of the study, which is based only on Romanian companies, it is appropriate to assess the impact of organizational structures on the development of CSR systems of companies on the basis of their division into mechanistic and organic organizational structures.

This article is meant to present the main differences in companies CSR approach taking into consideration the structures responsible within the organization. They were considered the two types of structures and a set of practices used to apply CSR. The article is structured as follows: the first section presents the CSR trend in Romania by making a brief review of the main studies used, in the second section is presented the research methodology describing the data and methods. The article continues with the main findings and the interpretation of the statistical analyses and the last part is assigned to research conclusions.

\section{studies}

CSR in Romania: the review of

The entry into the E.U. amplified
the use of CSR practices in the
Romanian business environment ${ }^{1}$. Moreover, the opportunities provided by the access to European funds played a major role in shaping companies perspectives towards CSR. Currently, in Romania, we can talk about "responsible industries" as sustainable businesses

\footnotetext{
${ }^{1}$ CSR in Romania. 2018. Available at: http://undp.ro/ libraries/projects/CSR/deliverables/Analiza\%20Situatiei\%20R SC\%20in\%20Romania\%20ENG.pdf (accessed 08.03.2016).
} 
that were able to make social and environmental activities and become core components of their business model. According to the research developed in the field [12-14], Romanian CSR is still in an early stage of development due to the lack of complex and continuous supportive measures.

Due to the market liberalization, the main promoters of these responsible business practices are the multinationals, that often transfer headquarter CSR perspectives and practices, to subsidiaries. Nevertheless, relevant to consider that the Western-style of CSR is spreading to the developing world, and the institutional forces play a major role in sustaining or obstructing such diffusion $[13 ; 15]$.

Considering the national academic studies, we can refer to some relevant researches that approached CSR. According to I.E. Iamandi [12], in Romania, there can be identified two CSR models: a model based on reciprocal strategy and a model based on shareholder strategy. D. Dobrescu and G. Vintilă [16] analyzed CSR practices focusing on environmental practices and their implications at the level of large companies operating in Romania. D.M. Lut [17] identified three main priorities when it comes to measuring CSR impact: environmental impact, companies' relation with human resources, and the companies' relation with the local community.

There were studies that observed the impact of CSR on listed companies, considering that these organizations are more likely to pay attention to their notoriety and trustworthiness on the market. Thus, L. Brad et al. [18] weighed up how Romanian listed companies report their social and environmental indicators and how these practices do not always lead to beneficial when it comes to financial performance. According to S.C. Gherghina and G. Vintilă [19], most of the CSR practices have a positive impact on the companies listed value, except for environmental protection practices. D. Dumitrescu and L. Simionescu [20] did not observe significant differences in the case of CSR companies and non-CSR companies in terms of financial performance.
C. Crisan-Mitra and A. Borza [21] through their study underline companies' perceptions of the CSR on the business key components, identifying three typologies of companies: one that recognizes CSR major influence on the overall business activity, once the sustainable practices are embodied in companies organizational culture; one having a more cost-benefit perspective based on the quantified inputs and outputs that can be clearly measured; and one that considers CSR as providing credibility and legitimacy to the company, with a major influence on investors decision to direct their money in socially responsible companies.

According to A.D. Serban [22], companies would rather respond to shareholders' questions or inquiries than having a proactive attitude towards people and the environment. O.I. Moisescu [23] examined the extent to which customers' loyalty to certain brands is influenced by the approach taken towards CSR, observing that these initiatives exert a significant positive influence on customers purchasing decision. C. Crisan-Mitra et al. [24] detected an inconsistency between customers' perceptions with respect to the company's environmental actions and what the company actually does to protect the environment. C. Stoian and R.M. Zacharia [25] studied how CSR affects employees and how they can actually become important players in the proliferation of CSR practices. Also, G.F. Grigore and A. Stancu [26] underlined the way employees and the community tend to associate responsible companies to those that behave in accordance with their rights, paying fair salaries and providing safe condition, and do not necessarily rely on complex CSR practices. According to C. Stoian and R.M. Zacharia [27] employees that had the experience of the socialist system, but are familiarized with CSR tend to act as channels for "hybrid CSR".

These results demonstrate an increased concern for companies' responsible behavior even if there is still much to say about the practices consistency and durability. Also, the relation between CSR, the company's economic performance and the impact 
created, is still not yet very clearly stated. Following this, the research meant to provide a perspective of the way CSR practices can be evaluated and measured in emerging countries.

As a developing country, Romania was taken into consideration for this study for three important reasons. First, there are very few studies made in developing countries in Europe and mostly if we refer to excommunist countries. Second, being among one of the latest countries that joined EU, it is still a country that faces major challenges when it comes to sustainability being exploited for the raw materials and cheap labour force, due to higher levels of energy consumption, imports, air, and water pollution and greater risks to the country's environment. Thus, without clear measures meant to institutionalize social and environmental development, Romania will remain in a vulnerable position in relation not only to other E.U. member states but also with other developed countries. Third, the case of Romania can be a relevant one for many developing countries that are committed to becoming EU members, being a relevant case to increasing measures and ensure sustainability.

\section{Research methodology and results}

7 he authors have resorted to conducting an empirical

1 research, based on investigation technique and the instrument used was the questionnaire. Multiple-choice questions using the Likert Scale, where 1 - "strongly disagree" and 5 - "totally agree". Data evaluation is based on the theoretical framework and the response processing was performed by applying mathematical models and statistical methods using MS Office Excel 2007, SPSS 17.0 and Statistical 7.0.

This study is designed to highlight how large companies' operating in Romania, approach CSR by identifying the existing differences in terms of practices used considering the organizational structures.

The respondent companies were CSR representatives from large companies (more than 249 employees) that operate on Romanian market (headquarters and subsidiaries). The companies that have agreed to participate in the study received from us a package that included a cover letter, an online questionnaire, and the credentials. 94 valid answers were obtained. Out of the total $75.86 \%$ were having a CSR organic structure while be rest declared that we're having a mechanical CSR structure. Also, 32.2 of the respondents were listed companies while 67.8 were non-listed companies, 64.4 were subsidiaries in Romania and the rest were headquarters

The limits of this study are given by the small number of respondents, which stems from the method used to disseminate the research instrument, the low availability the respondents to fill in the questionnaire, the lack of readiness and of social awareness, and the difficulty of finding suitable respondents to provide reliable answers.

The analyses started by evaluating the relation between companies CSR approach and CSR impact assessment. The use of external auditors enables a higher degree of commitment due to the indicators that must be accomplished reinforcing companies approach towards sustainable and reliable CSR practices. The McNewman test was applied to test the null hypothesis according to which there is no match between the companies pro-activeness towards CSR activities and the external audit practice. The test result rejects the null hypothesis and supports the alternative hypothesis $\mathrm{p}=0.008$, according to which companies that consider themselves to be proactive in term of CSR are assessed by external auditors. The homogeneity of the answers obtained was evaluated by testing how many of the managers that positively answer to the first question, use external audit for CSR practices. According to Marginal Homogeneity Test $=2.828, \quad \mathrm{p}=0.005$ respondents who considered the companies they work for as being CSR proactive are assessed by external auditors. It was further investigated the extent to which Global Reporting Initiative standards are considered relevant in assessing the degree of sustainability of the analysis. The test result validates the null hypothesis and rejects the alternative hypothesis $p=0.235$, so 
there is no significant match between the two dimensions. This states that companies that are using external audit fail to implement a sustainability plan in line with the rigor imposed by GRI standards.

The study continued with the test of the hypothesis considering the structures accountable (mechanistic or organic). Thus, it has been noticed that having an organic CSR structure, influences CSR practices used. The Kruskal Wallis test (Chi-Square $=12.75$, $\mathrm{p}=0.005)$ shows that the alternative hypothesis is accepted. Having a mechanistic structure typically implies additional resource and highlights the strategic role of sustainability policies in the company's core business. To evaluate the differences among companies with mechanistic and organic structure concerning the indicators/factors considered in the implementation of CSR practices was used the Kruskal Wallis test. According to the null hypothesis, it has been considered that no differences can be observed among both types. Kruskal Wallis test (Chi-Square $=192,159, \mathrm{p}=0,000)$ rejects the null hypothesis and the alternative is accepted, highlighting that the mechanistic or organic structure have different approaches in terms of items /factors of the CSR. To determine the cause of the differences between the two types of respondents, Mann Whitney U-test was used. The result ( $\mathrm{U}=440692, \quad \mathrm{p}=0.000)$, rejects the null hypothesis and the alternative is accepted, according to which the two groups of respondents appreciate the CSR factors differently.

The most important indicators/factors used due to the CSR implementation, regardless of the category they belong to mechanistic/organic structure are: "companies' image and reputation on the market", "procurement practices", "business partners human rights assessment", "industry trend on sustainable development". Not so important were considered to be, "customer pressure on social and environmental protection", "environmental grievance mechanisms", "the consumer-educated consumer education process", "committees, forums, departments involved in CSR".

Factors/indicators relevant to evaluate the company's CSR performance

\begin{tabular}{|c|l|c|c|c|}
\hline \multirow{2}{*}{ № } & \multicolumn{1}{|c|}{ Factors/Indicators } & Mean & $\begin{array}{c}\text { Mann-Whitney } \\
\text { U-test }\end{array}$ & p-value \\
\hline 1 & Companies' image and reputation on the market & 3.95 & 636 & 0.717 \\
\hline 2 & $\begin{array}{l}\text { Procurement practices (ex. compliance of business } \\
\text { partners/suppliers with the company's code of ethics) }\end{array}$ & 3.71 & 374 & 0.002 \\
\hline 3 & The use of ECO labels (ex. Fair Trade). & 3.49 & 558 & 0.43 \\
\hline 4 & Business partners human rights assessment. & 3.49 & 208 & 0 \\
\hline 5 & Industry trend regarding sustainable development & 3.49 & 574 & 0.538 \\
\hline 6 & Motivating and retaining talented employees & 3.44 & 624 & 0.947 \\
\hline 7 & Equal remuneration for women and men & 3.44 & 398 & 0.01 \\
\hline 8 & $\begin{array}{l}\text { Market presence (ex. market share, sales gained in the social } \\
\text { campaign) }\end{array}$ & 3.40 & 666 & 0.967 \\
\hline 9 & Fraud and false advertising & 3.26 & 464 & 0.066 \\
\hline 10 & The degree of companies' internationalization & 3.24 & 584 & 0.615 \\
\hline 11 & Training programs on codes of ethics of the employees & 3.24 & 240 & 0 \\
\hline 12 & Board independence & 3.24 & 388 & 0.008 \\
\hline 13 & Past anti-corruption/bribery policies & 3.23 & 522 & 0.238 \\
\hline 14 & Certification schemes (ex. ISO14000, EMAS, CERES, etc.) & 3.18 & 628 & 0.982 \\
\hline 15 & External economic conditions & 3.15 & 580 & 0.573 \\
\hline 16 & $\begin{array}{l}\text { Economic performance (ex. turnover, profitability, level of } \\
\text { indebtedness) }\end{array}$ & 3.14 & 444 & 0.019 \\
\hline 17 & Governmental/NGO's pressure & 3.14 & 392 & 0.008 \\
\hline 18 & $\begin{array}{l}\text { Social Practices (company's contributions to the local community, } \\
\text { community rights, jobs creation etc.) }\end{array}$ & 3.08 & 644 & 0.785 \\
\hline
\end{tabular}


The End of Table

\begin{tabular}{|c|l|c|c|c|}
\hline № & \multicolumn{1}{|c|}{ Factors/Indicators } & Mean & $\begin{array}{c}\text { Mann-Whitney } \\
\text { U-test }\end{array}$ & p-value \\
\hline 19 & $\begin{array}{l}\text { Shareholder satisfaction towards the social impact of CSR } \\
\text { policies }\end{array}$ & 2.94 & 554 & 0.397 \\
\hline 20 & Supplier environmental assessment & 2.86 & 618 & 0.895 \\
\hline 21 & $\begin{array}{l}\text { The degree to which employee is involved in the available forms } \\
\text { of participation to profits }\end{array}$ & 2.80 & 444 & 0.04 \\
\hline 22 & $\begin{array}{l}\text { Return of Socially Responsible Investments - SRI (ex. Financial } \\
\text { Times Stock Exchange Index) }\end{array}$ & 2.74 & 612 & 0.548 \\
\hline 23 & $\begin{array}{l}\text { Reporting method used for CSR performance (format and } \\
\text { verification) }\end{array}$ & 2.68 & 508 & 0.18 \\
\hline 24 & Committees, forums, panels, departments, etc. involved in CSR & 2.64 & 404 & 0.012 \\
\hline 25 & Consumer education process promoted by the company & 2.63 & 328 & 0.001 \\
\hline 26 & Environmental grievance mechanisms. & 2.40 & 508 & 0.182 \\
\hline 27 & Customer pressure (environment and social protection) & 2.33 & 480 & 0.102 \\
\hline
\end{tabular}

Evaluating comparatively the mechanistic and organic structures responsible with the CSR practices, several differences were observed between the two typologies considering the following items: "company performance", "acquisitions practices", "the consumer education process promoted by the company", "the extent to which employees are involved in the available forms of profit participation", "pressure exerted by state bodies/NGOs", "employee training on company code of ethics", "equal pay for women and men", "evaluation of business partners regarding respect for human rights", "committees, forums, departments involved in CSR", "independence of the board of directors in the decision-making process" (Table 2). In order to have a more detailed picture of the differences between the CSR approach from the perspective of the indicators/factors considered relevant to the CSR performance assessment, taking into account the responsible structures, we have noticed that the differences in the group's appreciation of the items: At the level of the companies that have a mechanistic CSR structure, the most important indicators in the implementation of CSR practices are: "company image and reputation on the market" $(\mathrm{M}=3.94)$, "business partners assessment of human rights" $(\mathrm{M}=3.82)$, "acquisition practice", "motivation and employee competence" ( $\mathrm{M}=3.63)$. The highest value registered in the case of respondents having an organic structure was also related to the company's image but the value highlights a greater relevance.

Table 2

Evaluating CSR practices considering the organizational structure used

\begin{tabular}{|c|c|c|c|c|c|c|c|c|c|c|c|}
\hline \multirow[b]{2}{*}{ № } & \multirow[b]{2}{*}{ Factors/indicators } & \multicolumn{5}{|c|}{ Mechanistic structure } & \multicolumn{5}{|c|}{ Organic structure } \\
\hline & & Mean & $\begin{array}{l}\text { Std. } \\
\text { Dev. }\end{array}$ & $\begin{array}{l}\text { Std. } \\
\text { Err. }\end{array}$ & $\mathbf{m}$ & M & Mean & $\begin{array}{l}\text { Std. } \\
\text { Dev. }\end{array}$ & $\begin{array}{l}\text { Std. } \\
\text { Err. }\end{array}$ & $\mathbf{m}$ & $\mathbf{M}$ \\
\hline 1 & $\begin{array}{l}\text { Companies' image and reputation on the } \\
\text { market }\end{array}$ & 3.94 & 1.166 & 0.142 & 1 & 5 & 4.2 & 0.41 & 0.092 & 4 & 5 \\
\hline 2 & $\begin{array}{l}\text { Business partners human rights } \\
\text { assessment }\end{array}$ & 3.82 & 1.313 & 0.16 & 1 & 5 & 2.4 & 0.503 & 0.112 & 1 & 4 \\
\hline 3 & $\begin{array}{l}\text { Procurement practices (ex.compliance of } \\
\text { business partners/suppliers with the } \\
\text { company's code of ethics) }\end{array}$ & 3.75 & 1.223 & 0.149 & 1 & 5 & 3.6 & 1.392 & 0.311 & 2 & 5 \\
\hline 4 & $\begin{array}{l}\text { Motivating and retaining talented } \\
\text { employees }\end{array}$ & 3.63 & 1.423 & 0.174 & 1 & 5 & 2.8 & 1.361 & 0.304 & 1 & 5 \\
\hline 5 & Equal remuneration for women and men & 3.63 & 1.423 & 0.174 & 1 & 5 & 2.8 & 1.361 & 0.304 & 1 & 5 \\
\hline 6 & The use of ECO labels (ex. Fair Trade) & 3.46 & 1.396 & 0.171 & 1 & 5 & 3.6 & 1.231 & 0.255 & 2 & 5 \\
\hline 7 & $\begin{array}{l}\text { Industry trend regarding sustainable } \\
\text { development }\end{array}$ & 3.46 & 1.491 & 0.182 & 1 & 5 & 3.6 & 0.821 & 0.184 & 3 & 5 \\
\hline 8 & $\begin{array}{l}\text { The degree of independence of the board } \\
\text { of directors in decisions making }\end{array}$ & 3.44 & 1.371 & 0.169 & 1 & 5 & 2.6 & 1.392 & 0.311 & 1 & 5 \\
\hline
\end{tabular}


The End of Table

\begin{tabular}{|c|c|c|c|c|c|c|c|c|c|c|c|}
\hline \multirow[b]{2}{*}{ № } & \multirow[b]{2}{*}{ Factors/indicators } & \multicolumn{5}{|c|}{ Mechanistic structure } & \multicolumn{5}{|c|}{ Organic structure } \\
\hline & & Mean & $\begin{array}{l}\text { Std. } \\
\text { Dev. }\end{array}$ & $\begin{array}{l}\text { Std. } \\
\text { Err. }\end{array}$ & $\mathbf{m}$ & $\mathbf{M}$ & Mean & $\begin{array}{l}\text { Std. } \\
\text { Dev. }\end{array}$ & $\begin{array}{l}\text { Std. } \\
\text { Err. }\end{array}$ & $\mathbf{m}$ & M \\
\hline 9 & $\begin{array}{l}\text { Market presence (ex. market share, } \\
\text { sales gained in the social campaign) }\end{array}$ & 3.4 & 1.303 & 0.159 & 1 & 5 & 3.4 & 1.046 & 0.234 & 2 & 5 \\
\hline 10 & $\begin{array}{l}\text { Anti-corruption or bribery policies } \\
\text { implemented within the past }\end{array}$ & 3.3 & 1.404 & 0.171 & 1 & 5 & 3 & 1.451 & 0.324 & 1 & 5 \\
\hline 11 & $\begin{array}{l}\text { Shareholder satisfaction towards the } \\
\text { social impact of CSR policies }\end{array}$ & 3.28 & 1.38 & 0.169 & 1 & 5 & 1.8 & 0.768 & 0.172 & 1 & 3 \\
\hline 12 & $\begin{array}{l}\text { The use of certification schemes (ex. } \\
\text { ISO14000, EMAS, CERES.) }\end{array}$ & 3.24 & 1.394 & 0.17 & 1 & 5 & 3 & 1.124 & 0.251 & 2 & 5 \\
\hline 13 & $\begin{array}{l}\text { Disputes arising from fraud and false } \\
\text { advertising }\end{array}$ & 3.22 & 1.423 & 0.174 & 1 & 5 & 3.4 & 1.046 & 0.234 & 2 & 5 \\
\hline 14 & $\begin{array}{l}\text { Training programs on codes of ethics } \\
\text { of the employees }\end{array}$ & 3.19 & 1.384 & 0.169 & 1 & 5 & 3.4 & 1.046 & 0.234 & 2 & 5 \\
\hline 15 & Governmental/NGO's pressure & 3.18 & 1.381 & 0.169 & 1 & 5 & 3 & 1.451 & 0.324 & 1 & 5 \\
\hline 16 & External economic conditions & 3.13 & 1.192 & 0.146 & 1 & 5 & 3.2 & 0.41 & 0.092 & 3 & 4 \\
\hline 17 & $\begin{array}{l}\text { Company contributions to the local } \\
\text { community, community rights, jobs } \\
\text { creation etc. }\end{array}$ & 3.1 & 1.416 & 0.173 & 1 & 5 & 3 & 1.298 & 0.29 & 1 & 5 \\
\hline 18 & $\begin{array}{l}\text { The degree of companies' } \\
\text { internationalization }\end{array}$ & 2.96 & 1.375 & 0.168 & 1 & 5 & 4.2 & 0.41 & 0.092 & 4 & 5 \\
\hline 19 & $\begin{array}{l}\text { Company performance (ex. turnover, } \\
\text { profitability, level of indebtedness) }\end{array}$ & 2.94 & 1.369 & 0.167 & 1 & 5 & 3.8 & 0.768 & 0.172 & 3 & 5 \\
\hline 20 & $\begin{array}{l}\text { The degree to which employee is } \\
\text { involved in the available forms of } \\
\text { participation to profits }\end{array}$ & 2.93 & 1.521 & 0.186 & 1 & 5 & 2.4 & 1.392 & 0.311 & 1 & 4 \\
\hline 21 & Supplier environmental assessment & 2.88 & 1.451 & 0.177 & 1 & 5 & 2.8 & 0.768 & 0.172 & 2 & 4 \\
\hline 22 & $\begin{array}{l}\text { Committees, forums, panels, } \\
\text { departments, etc. involved in CSR }\end{array}$ & 2.78 & 1.216 & 0.149 & 1 & 5 & 2.2 & 0.768 & 0.172 & 1 & 3 \\
\hline 23 & $\begin{array}{l}\text { Report type, format, and verification } \\
\text { of CSR performance }\end{array}$ & 2.76 & 1.327 & 0.162 & 1 & 5 & 2.4 & 0.503 & 0.112 & 2 & 3 \\
\hline 24 & $\begin{array}{l}\text { Return of Socially Responsible } \\
\text { Investments - SRI (ex. Financial } \\
\text { Times Stock Exchange Index) }\end{array}$ & 2.72 & 1.289 & 0.157 & 1 & 5 & 2.8 & 1.005 & 0.225 & 1 & 4 \\
\hline 25 & $\begin{array}{l}\text { Consumer education process } \\
\text { promoted by the company }\end{array}$ & 2.52 & 1.341 & 0.164 & 1 & 5 & 3 & 1.124 & 0.251 & 2 & 5 \\
\hline 26 & $\begin{array}{l}\text { Environmental grievance } \\
\text { mechanisms }\end{array}$ & 2.52 & 1.106 & 0.135 & 1 & 5 & 2 & 1.124 & 0.251 & 1 & 4 \\
\hline 27 & $\begin{array}{l}\text { Customer pressure (environment and } \\
\text { social protection) }\end{array}$ & 2.49 & 1.092 & 0.133 & 1 & 5 & 1.8 & 0.768 & 0.172 & 1 & 3 \\
\hline
\end{tabular}

Another aspect was to analyze the benefits of respondents included in the study and analyze the differences between the structures used. Thus, the benefits perceived by companies with mechanistic structure tend to be higher, but these differences are not significant: companies with a mechanistic (Mean=3.63, Std. Dev.=1.172), compared to those with the organic structure (Mean 3.39, Std. Dev.=1.344).

The statistical analysis continued with the Kolmogorov-Smirnov test $(\mathrm{p}=0.000)$ that show a normal distribution, and the Kruskal Wallis test was applied. To evaluate the correlation between the two typologies related to the perceived positive effects associated with the CSR practices and the organizational structures the following null hypothesis $\mathrm{H} 0$ was created. There are no differences in the appreciation of items $-\mathrm{H} 1$. There are differences in the appreciation of the items. The result of the Kruskal Wallis test is ChiSquare=7.336, $\mathrm{p}=0.001$, therefore, the null hypothesis is rejected. The results demonstrate that the two groups of respondents appreciate differently the CSR positive effects. To determine the difference between the typologies considered the U. Mann Whitney test was calculated (Table 3). 
Table 3

\section{Centralized identifiers - beneficial effects of CSR according to the structures used}

\begin{tabular}{|c|c|c|c|c|c|c|c|}
\hline \multirow[b]{2}{*}{ Organizational Structure } & \multirow[b]{2}{*}{ Mean } & \multirow[b]{2}{*}{ Std. Dev. } & \multirow[b]{2}{*}{$\mathbf{m}$} & \multirow[b]{2}{*}{$\mathbf{M}$} & \multicolumn{3}{|c|}{ Percentiles } \\
\hline & & & & & $25^{\text {th }}$ & $\begin{array}{c}\text { 50th } \\
\text { (Median) }\end{array}$ & 75th \\
\hline Mechanistic & 3.63 & 1.172 & 1 & 5 & 3.00 & 4.00 & 5.00 \\
\hline Organic & 3.39 & 1.344 & 1 & 5 & 3.00 & 4.00 & 4.75 \\
\hline
\end{tabular}

The mechanistic structure perceives as the main CSR benefits: "the increase company awareness to reach social legitimation", "improving the image and companies reputation", "strengthening companies' organizational culture". In the case of an organic structure, the main advantages were considered to be "increase company awareness to reach social legitimation", "improving the image and the reputation of the company as external perception". Not so important were considered in both cases the advantages: "easier access to European repayable funds", "obtaining tax incentives provided by the state/local institutions" and "attract new potential shareholders in the company" (Table 4).

CSR Benefits according to the organizational structure

\begin{tabular}{|c|c|c|c|c|c|c|c|c|c|c|c|}
\hline \multirow[b]{2}{*}{ № } & \multirow[b]{2}{*}{ CSR Benefits } & \multicolumn{5}{|c|}{ Mechanistic structure } & \multicolumn{5}{|c|}{ Organic structure } \\
\hline & & Mean & $\begin{array}{l}\text { Std. } \\
\text { Dev. }\end{array}$ & $\begin{array}{l}\text { Std. } \\
\text { Err. }\end{array}$ & $\mathbf{m}$ & $\mathbf{M}$ & Mean & $\begin{array}{l}\text { Std. } \\
\text { Dev. }\end{array}$ & $\begin{array}{l}\text { Std. } \\
\text { Err. }\end{array}$ & $\mathbf{m}$ & $\mathbf{M}$ \\
\hline 1 & Strengthen the company's overall strategy & 3.60 & 1.256 & 0.153 & 1 & 5 & 3.80 & 0.768 & 0.172 & 3 & 5 \\
\hline 2 & $\begin{array}{l}\text { Improving the image and the reputation of } \\
\text { the company as external perception }\end{array}$ & 4.34 & 1.095 & 0.134 & 1 & 5 & 4.40 & 0.821 & 0.184 & 1 & 5 \\
\hline 3 & $\begin{array}{l}\text { Increase company awareness to reach social } \\
\text { legitimation. }\end{array}$ & 4.38 & .873 & 0.107 & 1 & 5 & 4.10 & 1.411 & 0.308 & 1 & 5 \\
\hline 4 & Increase sales & 3.65 & 1.088 & 0.134 & 1 & 5 & 3.24 & 1.221 & 0.266 & 1 & 5 \\
\hline 5 & Raise market share & 3.56 & 1.125 & 0.138 & 1 & 5 & 3.14 & 1.276 & 0.278 & 1 & 5 \\
\hline 6 & $\begin{array}{l}\text { Improved ability to attract adequate } \\
\text { qualified human resources }\end{array}$ & 3.85 & 1.026 & 0.126 & 1 & 5 & 3.52 & 1.289 & 0.281 & 1 & 5 \\
\hline 7 & $\begin{array}{l}\text { Enhance the ability to attract, motivate and } \\
\text { retain talented employees }\end{array}$ & 3.76 & 1.266 & 0.156 & 1 & 5 & 3.52 & 1.401 & 0.306 & 1 & 5 \\
\hline 8 & Reduce operational costs & 3.11 & 1.229 & 0.151 & 1 & 5 & 2.71 & 1.309 & 0.286 & 1 & 5 \\
\hline 9 & $\begin{array}{l}\text { Attract new potential shareholders in the } \\
\text { company }\end{array}$ & 2.79 & 1.103 & 0.136 & 1 & 5 & 2.43 & 1.248 & 0.272 & 1 & 5 \\
\hline 10 & $\begin{array}{l}\text { Reduces resistance to change in } \\
\text { organizational transformation }\end{array}$ & 3.44 & 1.069 & 0.132 & 1 & 5 & 3.24 & 1.338 & 0.292 & 1 & 5 \\
\hline 11 & Expanding relations with public authorities & 3.80 & 1.084 & 0.133 & 1 & 5 & 3.57 & 1.434 & 0.313 & 1 & 5 \\
\hline 12 & Expanding relations with civil society & 3.95 & 1.087 & 0.134 & 1 & 5 & 3.76 & 1.300 & 0.284 & 1 & 5 \\
\hline 13 & $\begin{array}{l}\text { Obtaining tax incentives provided by the } \\
\text { state/local institutions }\end{array}$ & 3.03 & .976 & 0.120 & 1 & 4 & 3.10 & 1.221 & 0.266 & 1 & 4 \\
\hline 14 & Easier access to European repayable funds & 2.42 & .824 & 0.101 & 1 & 5 & 2.19 & 0.873 & 0.190 & 1 & 5 \\
\hline 15 & $\begin{array}{l}\text { Strengthening companies organizational } \\
\text { culture }\end{array}$ & 4.12 & .920 & 0.113 & 1 & 5 & 4.05 & 1.396 & 0.305 & 1 & 5 \\
\hline 16 & $\begin{array}{l}\text { Ensure the sustainable development of the } \\
\text { company }\end{array}$ & 3.88 & .903 & 0.111 & 1 & 5 & 3.67 & 1.390 & 0.303 & 1 & 5 \\
\hline 17 & $\begin{array}{l}\text { Enable the owners to have a more profound } \\
\text { sense of accomplishment }\end{array}$ & 4.00 & .961 & 0.118 & 1 & 5 & 3.43 & 1.287 & 0.281 & 1 & 5 \\
\hline 18 & $\begin{array}{l}\text { Ensure companies continuity across } \\
\text { generations }\end{array}$ & 3.68 & 1.166 & 0.143 & 1 & 5 & 3.14 & 1.276 & 0.278 & 1 & 5 \\
\hline
\end{tabular}

The mechanistic structure perceives as the main CSR benefits: "the increase company awareness to reach social legitimation", "improving the image and companies reputation", "strengthening companies' organizational culture". In the case of the organic structure, the main advantages were considered to be "increase company awareness 
to reach social legitimation", "improving the image and the reputation of the company as external perception". Not so important were considered in both cases the advantages: "easier access to European repayable funds", "obtaining tax incentives provided by the state/local institutions" and "attract new potential shareholders in the company".

The author used the assessment of the item's centrality indicators in each responsible
CSR group/type: H0. There are no differences between the appreciation of the beneficial effects between the type of respondents; $\mathrm{H} 1$. There are differences of positive effects perceptions in both cases. The data are not normally distributed, so the Mann-Whitney test ( $U=203667$; p-value 0.007) was decided based on the result of this test, and the alternative is accepted (Table 5).

CSR Benefits according to the organizational structure

\begin{tabular}{|c|l|c|c|}
\hline № & \multicolumn{1}{|c|}{ CSR Benefits } & $\begin{array}{c}\text { Mann-Whitney } \\
\text { U-test }\end{array}$ & p-value \\
\hline 1 & Strengthen the company's overall strategy & 644 & 0.784 \\
\hline 2 & Improving the image and the reputation of the company as external perception & 650 & 0.814 \\
\hline 3 & Increase company awareness to reach social legitimation & 594 & 0.386 \\
\hline 4 & Increase sales & 612 & 0.538 \\
\hline 5 & Raise market share & 626 & 0.644 \\
\hline 6 & Improved ability to attract adequate qualified human resources & 496 & 0.065 \\
\hline 7 & Enhance the ability to attract, motivate and retain talented employees & 668 & 0.983 \\
\hline 8 & Reduce operational costs & 558 & 0.244 \\
\hline 9 & Attract new potential shareholders in the company & 560 & 0.253 \\
\hline 10 & Reduces resistance to change in organizational transformation & 504 & 0.081 \\
\hline 11 & Expanding relations with public authorities & $\mathbf{3 9 2}$ & $\mathbf{0 . 0 0 4}$ \\
\hline 12 & Expanding relations with civil society & 584 & 0.353 \\
\hline 13 & Obtaining tax incentives provided by the state/local institutions & $\mathbf{2 5 2}$ & $\mathbf{0 . 0 0 0}$ \\
\hline 14 & Easier access to European repayable funds & 538 & 0.154 \\
\hline 15 & Strengthening companies organizational culture & $\mathbf{4 4 8}$ & $\mathbf{0 . 0 1 6}$ \\
\hline 16 & Ensure the sustainable development of the company & 502 & 0.074 \\
\hline 17 & Enable the owners to have a more profound sense of accomplishment & 638 & 0.735 \\
\hline 18 & Ensure companies continuity across generations & 660 & 0.916 \\
\hline
\end{tabular}

Thus it has been performed a determination of the items that registered differences, observing that the only differences in terms of the advantages identified are observed in the items "expanding relations with public authorities" (Mann-Whitney U=392, $\mathrm{p}=0.004)$, "strengthening organizational culture" (Mann-Whitney $\mathrm{U}=448 \mathrm{p}=0.016$ ), obtaining tax facilities (Mann-Whitney $\mathrm{U}=252$, $\mathrm{p}=0.000$ ).

\section{Conclusions}

7 his research reveals that the greatest majority of the companies included in the study have organic CSR structure. The decentralized decision-making, the dynamic structure, the freedom to perform a variety of tasks besides those with CSR specific, leads to less defined
CSR practices in the company's decisionmaking process being implemented especially for presentation, not as a part of a complex sustainability program. The economic, social and environmental strategies do not require complex measures, to justify the need for a mechanistic structure.

Moreover, GRI implementation is not considered as a priority, which further demonstrates that CSR is not considered to be a relevant indicator in influencing investors and increasing the performance of the company. However, it is noticed that the respondent's perception of the company's CSR strategy is constantly manifested, resulting in an encouraging immersion, based on significant and proactive initiatives, not required by current legislation, and relying 
more on companies willing to get involved in the economic, social and environmental development of the community in which they operate. Following the typology of the pursued standards with a focus on the social and environmental component, we noted an overwhelming majority respect a certain standard. Nevertheless, the GRI standard was not recognized by the respondents of being relevant for the assessment of CSR practices.

With regards to the specific differences in the impact of the type of organizational structure on the development of CSR, the following results have been obtained:

- participation of external auditors contributes to the fact that companies are more eager to achieve CSR indicators;

- regardless of belonging to a particular organizational structure, the most important factors that allow implementing CSR are: the company's image and its reputation at the market (3.95), procurement practice (3.71), business partners' assessment of human rights in the company, trends of sustainable development of the industry.

During the study the hypothesis that companies with mechanistic and organic organizational structures have different assessments of the role of factors of CSR has been confirmed. Thus, for companies with mechanistic structures, the most important factors contributing to the implementation of CSR are the company's image and reputation in the market (the average value is 3.9), business partners' assessment of human rights, procurement practices, motivation and competence of personnel. In organic structures the factor of "company image and reputation at the market" is also the most significant, but with a much larger average value (4.2).

From the view point of two organizational structures, the positive effect of CSR implementation is described mainly by the same set of factors, but they have different average significance assessment. For mechanistic structures it is raising awareness of a company to achieve social legitimation (4.38), improving the image and reputation of the company in the external perception (4.34), and strengthening the organizational culture (4.12). For organic structures it is primarily an improvement of the company's image and reputation in the external perception (4.40), as well as raising awareness of the company to achieve social legitimation (4.10).

In general, many times, CSR practices aim to remedy the harmful impact of the company's actions on the society, which cannot be avoided. Nevertheless, the organizations did not consider that performing CSR practices leads to obtaining tax incentives. Therefore, creating a clear and concise framework is more than necessary to promote both responsible behaviors, but also to provide remedies and sanctions in the event of non-compliance with the required framework. However, there is a growing tendency to raise awareness of the need for regulation not only at a macro level, but also at an organizational level, by establishing codes of conduct, human rights regulations, and core values and practices on CSR actions. Sometimes the introduction of sanctions can be both a stimulating factor for CSR actions, thereby diminishing social irresponsibility.

\section{References}

1. Idemudia U. Corporate social responsibility and developing countries: Moving the critical CSR research agenda in Africa forward. Progress in Development Studies, 2011, vol. 11, iss. 1, pp. 1-18.

2. Burns T., Stalker G.M. The Management of innovation. Tavistock Publ., London, 1962. 269 p.

3. Weick K.E., Browning L.D. Argument and narration in organizational communication. Journal of Management, 1986, vol. 12, iss. 2, pp. 243-259.

4. Morand D.A. The role of behavioural formality and informality in the enactment of bureaucratic versus organic organizations. Academy of Management Review, 1995, vol. 20, no. 4, pp. 831-872.

5. Blau J.R., Alba R.D. Empowering nets of participation. Administrative Science Quaterly, 1982, vol. 27, no. 3, pp. 363-379.

6. Poza E.J, Markus L. Success story: The team approach to work restructuring. Organizational Dynamics, 1980, vol. 3, pp. 3-25. 
7. Manz C.C., Sims H.P. Leading self-managed groups: A conceptual analyses of a paradox. Economic and Industrial Democracy, 1986, vol. 7, iss. 2, pp. 141-165.

8. Walton R.E., Schlesinger L.A. Do supervisors thrive in participative work systems? Organizational Dynamics, 1979, vol. 7, no. 3, pp. 24-38.

9. Albers S., Wohlgezogen F., Zajac E.J. Strategic alliance structures: An organization design perspective. Journal of Management, 2016, vol. 42, no. 3, pp. 582-614. doi: 10.1177/0149206313488209.

10. Young-Hyman T. Cooperating without co-laboring: How formal organizational power moderates cross-functional interaction in project teams. Administrative Science Quarterly, 2017, vol. 62, iss. 1, pp. 179-214.

11. Perez-Valls M., Cespedes-Lorente J., Martınez-del-R1o J., Antolın-Lopez R. How organizational structure affects ecological responsiveness. Business and Society, 2017, pp. 1-37. doi: $10.1177 / 0007650317696313$.

12. Iamandi I.E. The application of corporate social responsibility models in Romania in the context of the post-accession to the European Union. Economy Transdisciplinary Cognition, 2011, vol. 14, iss. 1, pp. 27-34.

13. Crisan-Mitra C., Borza A. How measuring CSR performance impacts CSR results. Interdisciplinary Management Research, 2015, vol. 11, pp. 869-879.

14. Popa R.A. The corporate social responsibility practices in the context of sustainable development. The case of Romania. Procedia Economics and Finance, 2015, vol. 23, pp. 1279-1285. doi: 10.1016/S22125671(15)00395-0.

15. Jamali D. Neville B. Convergence versus divergence of CSR in developing countries: An embedded multi-layered institutional lens. Journal of Business Ethics, 2011, vol. 102, iss. 4, pp. 599-621.

16. Dobrescu D., Vintilă G. Analysis of environmental corporate social responsibility - Romania in globalization context. Journal of Environmental Protection and Ecology, 2014, vol. 15, no. 4, pp. 1660-1670.

17. Lut D.M. Corporate social responsibility policy within the Romanian west region companies. Quaestus, 2015, no. 7, pp. 9-18.

18. Brad L., Dobre F., Tुurlea C., Brasoveani I.V. The impact of IFRS adoption in Romania upon the earnings management of the Bucharest Stock exchange entities. Procedia Economics and Finance, 2014, vol. 15, pp. 871-876. doi: 10.1016/S2212-5671(14)00550-4.

19. Gherghina S.C., Vintilă G. Exploring the impact of corporate social responsibility policies on firm value: The case of listed companies in Romania. Economics and Sociology, 2016, vol. 9, no. 1, pp. $23-$ 42. doi: 10.14254/2071-789X.2016/9-1/2.

20. Dumitrescu D., Simionescu L. Corporate social responsibility (CSR) and company financial performance: Empirical evidence from listed companies in Romania. Entrepreneurship, Business and Economics, 2016, vol. 2, pp. 677-689.

21. Crişan-Mitra C., Borza A. Approaching CSR in Romania: An empirical analysis. Procedia-Social and Behavioral Sciences, 2015b, vol. 207, pp. 546-552. doi: 10.1016/j.sbspro.2015.10.125.

22. Serban A.D. CSR as Corporate power. A communication view Facebook approach: An exploratory study. Management Dynamics in the Knowledge Economy, 2016, vol. 4, no. 1, pp. 31-61.

23. Moisescu O.I. Demographics-based differences in the relationship between perceived CSR and customer loyalty in the dairy products market. Management and Marketing, 2015, vol. 10, iss. 2, pp. 118-131.

24. Crisan-Mitra C., Dinu V., Postelnicu C., Dabija D.C. Corporate practice of sustainable development on an emerging market. Transformations in Business and Economics, 2016, vol. 15 (1), pp. 228-243.

25. Stoian C., Zaharia R.M. CSR development in post-communist economies: Employees' expectations regarding corporate socially responsible 157ehaviour - the case of Romania. Business Ethics: A European Review, 2012, vol. 21, iss. 4, pp. 380-401.

26. Grigore G.F., Stancu A. The role of corporate social responsibility in building employer's brand. Transformation in Business and Economics, 2011, vol. 10, no. 2B (23B), pp. 741-753. 


\section{Information about the Author}

Crisan-Mitra Catalina Silvia - Associate Professor at the Department of Management, Faculty of Economics and Business Administration, Babes-Bolyai University (58-60, Teodor Mihali st., Cluj-Napoca, 400591, Romania; e-mail: catalina.crisan@econ.ubbcluj.ro).

\section{Список литературы}

1. Idemudia $U$. Corporate social responsibility and developing countries: Moving the critical CSR research agenda in Africa forward // Progress in Development Studies. 2011. Vol. 11, Iss. 1. P. 1-18.

2. Burns T., Stalker G.M. The Management of innovation. London: Tavistock Publ., 1962. 269 p.

3. Weick K.E., Browning L.D. Argument and narration in organizational communication // Journal of Management. 1986. Vol. 12, Iss. 2. P. 243-259.

4. Morand D.A. The role of behavioural formality and informality in the enactment of bureaucratic versus organic organizations // Academy of Management Review. 1995. Vol. 20, № 4. P. 831-872.

5. Blau J.R., Alba R.D. Empowering nets of participation // Administrative Science Quaterly. 1982. Vol. 27, № 3. P. 363-379.

6. Poza E.J, Markus L. Success story: The team approach to work restructuring // Organizational Dynamics. 1980. Vol. 3. P. 3-25.

7. Manz C.C., Sims H.P. Leading self-managed groups: A conceptual analyses of a paradox // Economic and Industrial Democracy. 1986. Vol. 7, Iss. 2. P. 141-165.

8. Walton R.E., Schlesinger L.A. Do supervisors thrive in participative work systems? // Organizational Dynamics. 1979. Vol. 7, № 3. P. 24-38.

9. Albers S., Wohlgezogen F., Zajac E.J. Strategic alliance structures: An organization design perspective // Journal of Management. 2016. Vol. 42, № 3. P. 582-614. doi: 10.1177/0149206313488209.

10. Young-Hyman T. Cooperating without co-laboring: How formal organizational power moderates cross-functional interaction in project teams // Administrative Science Quarterly. 2017. Vol. 62, Iss. 1. P. 179-214.

11. Perez-Valls M., Cespedes-Lorente J., Martınez-del-Rıo J., Antolın-Lopez R. How organizational structure affects ecological responsiveness // Business and Society. 2017. P. 1-37. doi: $10.1177 / 0007650317696313$.

12. Iamandi I.E. The application of corporate social responsibility models in Romania in the context of the post-accession to the European Union // Economy Transdisciplinary Cognition. 2011. Vol. 14, Iss. 1. P. 27-34.

13. Crisan-Mitra C., Borza A. How measuring CSR performance impacts CSR results // Interdisciplinary Management Research. 2015. Vol. 11. P. 869-879.

14. Popa R.A. The corporate social responsibility practices in the context of sustainable development. The case of Romania // Procedia Economics and Finance. 2015. Vol. 23. P. 1279-1285. doi: 10.1016/S22125671(15)00395-0.

15. Jamali D. Neville B. Convergence versus divergence of CSR in developing countries: An embedded multi-layered institutional lens // Journal of Business Ethics. 2011. Vol. 102, Iss. 4. P. 599-621.

16. Dobrescu D., Vintilă G. Analysis of environmental corporate social responsibility - Romania in globalization context // Journal of Environmental Protection and Ecology. 2014. Vol. 15, № 4. P. 1660-1670.

17. Lut D.M. Corporate social responsibility policy within the Romanian west region companies // Quaestus. 2015. № 7. P. 9-18.

18. Brad L., Dobre F., Thurlea C., Brasoveani I.V. The impact of IFRS adoption in Romania upon the earnings management of the Bucharest Stock exchange entities // Procedia Economics and Finance. 2014. Vol. 15. P. 871-876. doi: 10.1016/S2212-5671(14)00550-4.

19. Gherghina S.C., Vintilă G. Exploring the impact of corporate social responsibility policies on firm value: The case of listed companies in Romania // Economics and Sociology. 2016. Vol. 9, № 1. P. $23-$ 42. doi: 10.14254/2071-789X.2016/9-1/2.

20. Dumitrescu D., Simionescu L. Corporate social responsibility (CSR) and company financial performance: Empirical evidence from listed companies in Romania // Entrepreneurship, Business and Economics. 2016. Vol. 2. P. 677-689.

21. Crişan-Mitra C., Borza A. Approaching CSR in Romania: An empirical analysis // ProcediaSocial and Behavioral Sciences. 2015. Vol. 207. P. 546-552. doi: 10.1016/j.sbspro.2015.10.125. 
22. Serban A.D. CSR as Corporate power. A communication view Facebook approach: An exploratory study // Management Dynamics in the Knowledge Economy. 2016. Vol. 4, № 1. P. 31-61.

23. Moisescu O.I. Demographics-based differences in the relationship between perceived CSR and customer loyalty in the dairy products market // Management and Marketing. 2015. Vol. 10, Iss. 2. P. 118-131.

24. Crisan-Mitra C., Dinu V., Postelnicu C., Dabija D.C. Corporate practice of sustainable development on an emerging market // Transformations in Business and Economics. 2016. Vol. 15 (1). P. 228-243.

25. Stoian C., Zaharia R.M. CSR development in post-communist economies: Employees' expectations regarding corporate socially responsible behaviour - the case of Romania // Business Ethics: A European Review. 2012. Vol. 21, Iss. 4. P. 380-401.

26. Grigore G.F., Stancu A. The role of corporate social responsibility in building employer's brand. Transformation in Business and Economics, 2011, Vol. 10, № 2B (23B). P. 741-753.

Статья поступила в редакиию 16.11.2018, принята к печати 23.01.2019

\section{Сведения об авторе}

Крисан-Митра Каталина Сильвия - доцент кафедры менеджмента, факультет экономики и делового администрирования, Университет Бабеш-Бойяи (Румыния, 400591, г. Клуж-Напока, ул. Теодора Михали, 58-60; e-mail: catalina.crisan@econ.ubbcluj.ro).

Просьба ссылаться на эту статью в русскоязычных источниках следующим образом: Crisan-Mitra C.S. Organizational structure as a factor of development of corporate social responsibility in Romanian companies // Вестник Пермского университета. Сер. «Экономика» $=$ Perm University Herald. Economy. 2019. Том 14. № 1. C. 145-159. doi: 10.17072/1994-99602019-1-145-159

\section{Please cite this article in English as:}

Crisan-Mitra C.S. Organizational structure as a factor of development of corporate social responsibility in Romanian companies. Vestnik Permskogo universiteta. Seria Ekonomika = Perm University Herald. Economy, 2019, vol. 14, no. 1, pp. 145-159. doi: 10.17072/1994-9960-2019-1-145-159 